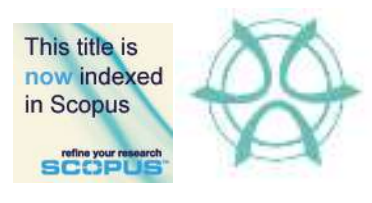

PLANNING MALAYSIA:

Journal of the Malaysian Institute of Planners

VOLUME 18 ISSUE 4 (2020), Page 173 - 190

\title{
THE INFLUENCE OF URBAN PLANNING ON MENTAL HEALTH. CASE STUDY: FEDERAL TERRITORY OF KUALA LUMPUR
}

\author{
Marlyana Azyyati Marzukhi', Nur Masyitah Ghazali ${ }^{2}$, Oliver Ling Hoon Leh ${ }^{3}$, \\ Nurul Shakila Khalid ${ }^{4}$, Siti Mazwin Kamaruddin ${ }^{5}$, Muhammad Farid Azizul ${ }^{6}$ \\ ${ }^{1-5}$ Center of Studies for Town and Regional Planning, \\ Faculty of Architecture, Planning and Surveying, \\ UNIVERSITI TEKNOLOGI MARA, \\ ${ }^{6}$ Department of Landscape Architecture, \\ Faculty of Built Environment, \\ UNIVERSITI TEKNOLOGI MALAYSIA
}

\begin{abstract}
The health impacts of the development and environment have been widely assessed, but little is known about the impact of physical characteristics of urban planning on people's mental well-being. Thus, this research is crucial to understand the mental health challenges of urban population in Malaysia. The objective of this research is to examine the influence of urban planning on mental health, particularly the attributes of urban planning, density and land use, as well as their potential relation to psychological stress, depression and anxiety. The study was carried out at low-cost flats at Pantai Dalam in Federal Territory of Kuala Lumpur. Besides the secondary data collection and site observation, a survey in a form of questionnaire that used Depression Anxiety Stress Scale (DASS-21) was distributed. The findings showed that density and land use contributed to mental disorders. The research findings can be applied by government agencies, professionals and private sectors to plan healthier urban physical environment. This research will add to the growing literature that suggests the importance of the built environment in shaping mental health.
\end{abstract}

Keywords: Anxiety, built environment, density, depression, land use, mental disorders, stress.

\footnotetext{
${ }^{1}$ Senior Lecturer at UiTM, Puncak Alam, Selangor. Email: marlyana@uitm.edu.my
} 
Marzukhi, M.A., Ghazali, M.A., Oliver Ling Hoon Leh, Khalid, N.S., Kamaruddin, S.M., Azizul, M.F.

The Influence of Urban Planning on Mental Health. Case Study: Federal Territory of Kuala Lumpur

\section{INTRODUCTION}

According to United Nations (UN) Habitat (2017), almost 60 per cent of the world's population predicted to live in urban areas by 2030. Srivasta (2009) remarked that urbanisation is defined as an increase in the number of cities and urban populations, which includes changes in demographic movement, as well as social, economic and psychological aspects. The level of urbanisation changes the economic structure and causes the rural population to migrate to the urban area. This condition creates overpopulated areas, and thus, demand housing will increase, as well as a higher density housing scheme will be built. Hence, this causes a low quality of housing and inadequate provision of facilities, including the green area and public spaces. This rapid urbanisation exerts pressure on the environment and health of the urban population, including Malaysia. In fact, Evans (2003) claimed that built environments, which have the characteristics of housing, crowding, noise, indoor air quality, and light can affect mental health directly and indirectly.

In this sense, urban planning and mental health are interdependent in many ways. However, there is rarely any attempt to try to understand the broader origins, implications and possibilities to develop strategies or framework coordinating the relationship between urban environment and mental health (Adli et al., 2017). Understanding on how urban planning influences mental health is central as "health extends far beyond medical care" (Schema, 2018). Therefore, this research is important to achieve the objectives: to examine the influence of urban planning on mental health and to analyse the spatial relationship of the urban physical environment on mental disorders.

\section{LITERATURE REVIEW}

Urbanisation is transforming the fabric of cities. By 2030, an estimated one in every three people from 60 per cent of the world's population will live in cities with at least a million of inhabitants (United Nations, 2016). Understanding of this increasing urbanisation is critical as a physical form of the urban environment poses massive sustainability challenges including health (The New Urban Agenda, 2017). Stressors, social density, and social isolation are also health determinants that occur more frequently in cities than in rural areas (The Lancet Psychiatry, 2017). New Urban Agenda adopted at the Habitat III cities conference in Quito, in October 2016 has indicated the improvement of human health and well-being as a key priority to achieve sustainable development goals. In fact, World Urban Forum 9 (WUF 9), in February 2018 has concluded with Kuala Lumpur Declaration on Cities 2030 (2018) to localise the implementation of New Urban Agenda that highlights the concept of Cities for All. This seeks to address the major challenges of rapid urbanisation, including producing healthy and sustainable cities, as well as fostering prosperity and quality of life for all. Urbanisation is vital in urban planning, especially to health challenges in the $21^{\text {st }}$ 
PLANNING MALAYSIA

Journal of the Malaysia Institute of Planners (2020)

century (World Health Organization, 2008). Many researchers indicated that living in urban areas might double the risks of schizophrenia and increase the chances of anxiety disorders by 21 per cent, mood disorders by 39 per cent and depression by 20 per cent (Byrne, 2017). Despite this interest, the interrelationships between urban planning and health practitioners are somehow limited (Adli et al., 2017; Douglas et al., 2017). It is plausible that these fields influence each other over time. Therefore, understanding this sequencing is vital for understanding their association. Reflecting this, it is worth quoting Sarkar and Webster (2017) at length:

"A deeper understanding of the relationships between urban environment and human health will help devise effective preventive interventions towards minimising/offsetting environmental risk exposures reducing resulting health burdens, lead to healthy lifestyle and behaviour and thereby fulfil the goals of sustainable development."

Numerous works of literature has investigated on the relationship between characteristics of the urban physical environment and physical health (Fisher et al., 2017; Lau et al., 2018; Ling et al., 2020; Nurul Ashikin et al., 2018; Richardson et al., 2013). Nevertheless, little is known about the effects of urban planning on the mental health of the urban population (Adli et al., 2017; Gruebner et al., 2017). Thus, this research is important to meet the crucial aspect of planning and health challenges of contemporary mass urbanisation which will cause a transformative effect on the lives of the community.

Mental health refers to "a state of well-being, in which every individual realises his or her potential, who can cope with the normal stresses of life, can work productively and fruitfully, and is able to make a contribution to her or his community" (WHO, 2014; 2018). What is worse, in Malaysia, four out of every ten Malaysians will suffer a mental health issue causing the number of mental health issues to increase (The Star, 2017). Mental health is defined in this research as the psychological symptoms of stress, depression and anxiety, but not psychiatric conditions, such as schizophrenia disorders and bipolar disorder (WHO, 2014). The urban planning or urban physical environment is one of the potential determinants of mental disorders (Sarkar \& Webster, 2017). Helbich (2018) elucidated that "[i]t is increasingly recognised that mental disorders are affected by both personal characteristics and environmental exposures." From this viewpoint, the physical environment seems to have direct and indirect effects on mental health that may elevate psychological stress, depression and anxiety.

\section{Attributes of Urban Planning to Mental Health}

The urban physical environment is important to health and well-being as it can influence the city's liveability and people's behaviour. The urban physical 
Marzukhi, M.A., Ghazali, M.A., Oliver Ling Hoon Leh, Khalid, N.S., Kamaruddin, S.M., Azizul, M.F.

The Influence of Urban Planning on Mental Health. Case Study: Federal Territory of Kuala Lumpur

environment can also encourage or discourage a person from being active and improve an individual's ability to strive against an unhealthier lifestyle (Rebecchi, 2019). In this sense, the rapid pace of urbanisation and urban planning may play a particular role in shaping the mental health of the urban population.

\section{Density}

Urban density is calculated as the ratio of built volume over an area. Town and Country Planning Act 1976 (Act 172) described density as "the intensity of use of land reckoned or expressed in term of number of persons, dwelling units, or habitable rooms or combination of those factors, per unit area of land". Kuala Lumpur City Hall (DBKL) in Kuala Lumpur City Plan 2020 defined density as the number of persons to the land area in assisting of population distribution, as well as planning for facilities, utilities, infrastructure and service. Meanwhile, the definition of high-density cities by Second National Urbanisation Policy is a city that relies on diverse land uses, optimising public transportation systems and promoting walking and cycling. High density or overcrowding areas can give effect to mental health. There is an evidence that shows the floor area ratio and building density is positively associated with mental health (Qiu et al., 2019).

\section{Land Use}

Land use is one of urban planning attribute which might have associations with mental health. Land use consists of types of development and location for land use mix at three different land uses, which are residential, commercial and industrial. Miles et al. (2011) found an evidence that land-use diversity has adverse effects on mental health. Urban growth causes expansion of slums, exposure to hazardous conditions resulting in a location near to industries and dense traffic areas that affect the mental health of the residents (BMJ, 2017). Land use is vital in shaping a city by an urban planner and local authority. The location for each land use, such as residential, commercial, industrial, and green area should be suitable to create a more liveable city as the urban area continues to expand in the population (WHO, 2018).

\section{RESEARCH METHODOLOGY}

\section{Study Area}

This study focused on the influence of urban planning on mental health, which was the low-cost flat at Pantai Dalam. The area was selected due to the denselypopulated housing area with a minimum provision of facilities and a lack of privacy. There were two low-cost flats selected which were PPR Pantai Ria and PPR Kerinchi Lembah Pantai. The total area of Pantai Ria low-cost flats is 9.41 acres, while the total area of Kerinchi Lembah Pantai low-cost flats is 11.12 acres. Both study areas of the low-cost flats were in Federal Territory of Kuala Lumpur within the administrative boundary of Kuala Lumpur City Hall (DBKL). Pantai 
PLANNING MALAYSIA

Ria low-cost flats are located near to Pantai Dalam commuter station, while Kerinchi Lembah Pantai low-cost flats are located near to Pantai Hillpark which can access with New Pantai Expressway (NPE). The Pantai Ria flats are located near to Pantai Sewerage Treatment Plant 2 and Pantai Eco Park Community Center. Besides that, the Pantai Ria flats' location is beside Klang River (see Figure 1). For the Kerinchi Lembah Pantai flats, they are located near to Bazaria Pantai, Lembah Pantai Library Complex and Masjid Al-Iklasiah.

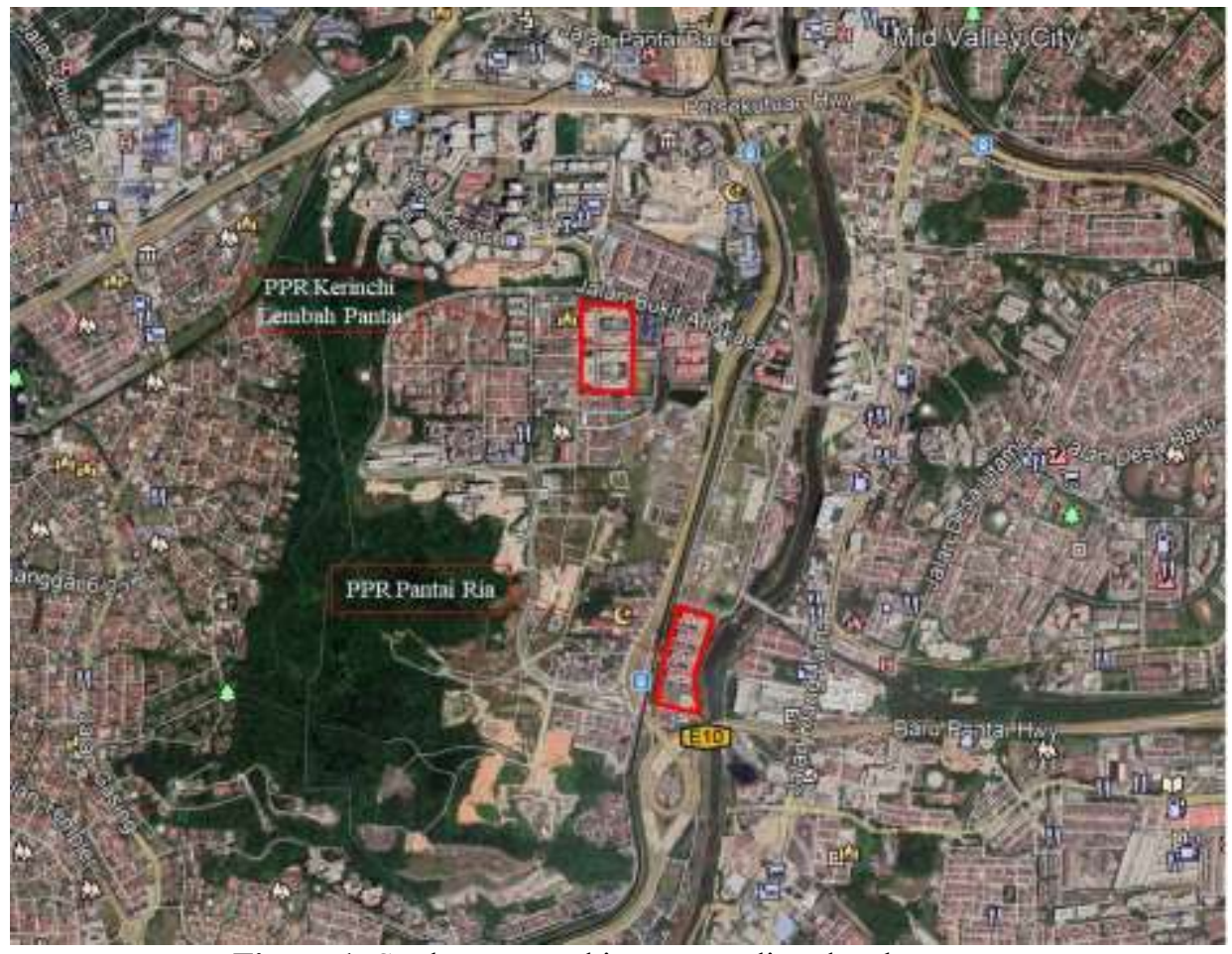

Figure 1: Study areas and its surrounding developments

\section{Questionnaire Survey and Sampling of Respondents}

The influence of urban planning on mental health was identified through a survey in a form of questionnaire. Stratified random sampling was ideal for respondents' selection because this research consisted of a survey in a form of questionnaire administered to the respondents who may experience mental disorder problems or without mental disorder problems. These respondents were chosen randomly, which represented the total population of the selected areas.

The questionnaire emphasised on identifying the public's opinions about the two attributes of urban planning to mental health, which were density and land use, as well as a checklist of adaptation on Depression Anxiety Stress Scales (DASS-21). A total of 102 respondents were selected from the total 
Marzukhi, M.A., Ghazali, M.A., Oliver Ling Hoon Leh, Khalid, N.S., Kamaruddin, S.M., Azizul, M.F.

The Influence of Urban Planning on Mental Health. Case Study: Federal Territory of Kuala Lumpur

population of 17,388 in the study areas by using Raosoft Sample Size Calculator. The samples were determined with the confidence level of 92 per cent with the amount of response distribution of 50 per cent. A four-point Likert type scaled items were set up, in which the respondents were asked to indicate their assessment to measure the emotional states of depression, anxiety and stress. The samples covered both males and females, different ethnic groups and different age groups (see Table 1).

Table 1: Background of respondents

\begin{tabular}{cr}
\hline Variables & Percentage (\%) \\
Gender & 52.0 \\
Male & 48.0 \\
Female & \\
Ethnicity & 74.50 \\
Malay & 4.90 \\
Chinese & 19.60 \\
Indian & 1.00 \\
Others & \\
Age & 12.70 \\
15-24 years old & 23.50 \\
25-34 years old & 23.50 \\
35-44 years old & 26.50 \\
45-54 years old & 11.80 \\
55-64 years old & 2.00 \\
$>65$ years old & \\
\hline
\end{tabular}

\section{Method of Analysis}

Data analysis for this research was based on a questionnaire and checklist of adaptation on Depression Anxiety Stress Scales (DASS-21). The data were analysed using frequency and correlation tests as provided in the IBM SPSS software.

\section{RESULTS AND FINDINGS}

The results of this analysis were summarised in Table 2. The results of states of depression, anxiety and stress were self-reported scales using DASS-21. From the DASS-21 scores, the severity states of depression, anxiety and stress were calculated. In Table 2, it was shown that the respondents who have a normal state for depression were equal with 33 respondents (64.7\%) for both PPR Pantai Ria and PPR Kerinchi Lembah Pantai. Nonetheless, based on the results, the respondents at PPR Pantai Ria had a higher percentage of extremely severe depression, which was 7.8 per cent as compared to the respondents at PPR Kerinchi Lembah Pantai, which was 5.9 per cent only. 
Based on the results, it was also displayed that a normal state of anxiety at PPR Pantai Ria was 58.8 per cent, while at PPR Kerinchi Lembah Pantai, it was 52.9 per cent. This indicated that PPR Kerinchi Lembah Pantai had slightly more respondents having anxiety as compared to PPR Pantai Ria. Conversely, PPR Pantai Ria exhibited a higher percentage of extremely severe anxiety cases as compared to PPR Kerinchi Lembah Pantai. Most of the respondents with anxiety at PPR Kerinchi Lembah Pantai were at the states of mild or moderate (see Table 2).

For the states of stress severity, based on the results (see Table 2), the percentage of respondents with normal states of stress was also higher at PPR Pantai Ria, which was 58.8 per cent. In contrast, the percentage of respondents having extremely severe stress, was higher at PPR Pantai Ria, which was 3.9 per cent.

Based on the findings from Table 2, the percentages of respondents having extremely severe states of depression, anxiety and stress were higher at PPR Pantai Ria as compared to PPR Kerinchi Lembah Pantai.

Table 2: The respondents' severity states of depression, anxiety and stress

\begin{tabular}{|c|c|c|c|c|c|c|c|c|c|c|c|c|}
\hline \multirow[t]{3}{*}{ Severity } & \multicolumn{4}{|c|}{ Depression } & \multicolumn{4}{|c|}{ Anxiety } & \multicolumn{4}{|c|}{ Stress } \\
\hline & \multicolumn{2}{|c|}{$\begin{array}{l}\text { PPR Pantai } \\
\text { Ria }\end{array}$} & \multicolumn{2}{|c|}{$\begin{array}{c}\text { PPR } \\
\text { Kerinchi } \\
\text { Lembah } \\
\text { Pantai }\end{array}$} & \multicolumn{2}{|c|}{$\begin{array}{l}\text { PPR Pantai } \\
\text { Ria }\end{array}$} & \multicolumn{2}{|c|}{$\begin{array}{c}\text { PPR } \\
\text { Kerinchi } \\
\text { Lembah } \\
\text { Pantai }\end{array}$} & \multicolumn{2}{|c|}{$\begin{array}{c}\text { PPR Pantai } \\
\text { Ria }\end{array}$} & \multicolumn{2}{|c|}{$\begin{array}{c}\text { PPR } \\
\text { Kerinchi } \\
\text { Lembah } \\
\text { Pantai }\end{array}$} \\
\hline & Nos & $\%$ & Nos & $\%$ & Nos & $\%$ & Nos & $\%$ & Nos & $\%$ & Nos & $\%$ \\
\hline Normal & 33 & 64.7 & 33 & 64.7 & 30 & 58.8 & 27 & 52.9 & 30 & 58.8 & 28 & 54.9 \\
\hline Mild & 8 & 15.7 & 6 & 11.8 & 7 & 13.7 & 8 & 15.7 & 8 & 15.7 & 6 & 11.8 \\
\hline Moderate & 5 & 9.8 & 6 & 11.8 & 6 & 11.8 & 9 & 17.6 & 5 & 9.8 & 11 & 21.6 \\
\hline Severe & 1 & 2.0 & 3 & 5.9 & 5 & 9.8 & 5 & 9.8 & 6 & 11.8 & 6 & 11.8 \\
\hline $\begin{array}{l}\text { Extremely } \\
\text { Severe }\end{array}$ & 4 & 7.8 & 3 & 5.9 & 3 & 5.9 & 2 & 3.9 & 2 & 3.9 & 0 & 0 \\
\hline Total & 51 & 100 & 51 & 100 & 51 & 100 & 51 & 100 & 51 & 100 & 51 & 100 \\
\hline
\end{tabular}

\section{Mental Health and Density}

High density would cause crowding when the number of populations per acre was higher and uncontrolled crowding would cause overcrowding. Crowding was also involved in the neighbourhood and in-house crowding. The residents of low-cost housing were from a low-income group, and the number of households was also higher. The total numbers of a housing unit for the study area were 1,264 for PPR Pantai Ria and 1,896 for PPR Kerinchi Lembah Pantai respectively with 17 floors for both. The estimation of people who live per floor was 99, and the unit number per floor was 20 for both PPR Pantai Ria and PPR Kerinchi Lembah Pantai. 
Marzukhi, M.A., Ghazali, M.A., Oliver Ling Hoon Leh, Khalid, N.S., Kamaruddin, S.M., Azizul, M.F. The Influence of Urban Planning on Mental Health. Case Study: Federal Territory of Kuala Lumpur

In general, PPR Kerinchi Lembah Pantai had a more density than PPR Pantai Ria based on the number of people per acre (see Table 3). On a contrary, based on observation, PPR Pantai Ria was more crowded including the environment at the parking area (see Photo 1). The spaces between residential blocks at PPR Pantai Ria were 40 metres as compared to PPR Kerinchi Lembah Pantai which had a greater distance of 75 metres. The road width for PPR Pantai Ria was also at a minimum width of 6 metres which was for one-way and insufficient provision of car parking. This caused the road overcrowded with the car parked on both sides of the road. The road width at PPR Kerinchi Lembah Pantai was 7.3 metres which was for two-ways. PPR Kerinchi Lembah Pantai had a housing unit size of 800 square feet, while PPR Pantai Ria had a housing unit size 750 square feet that illustrated the housing units size had a difference of 50 square feet. Even though the numbers of units, acreage, number of blocks, and density of PPR Kerinchi Lembah Pantai were higher than PPR Pantai Ria, the environment at PPR Pantai Ria showed that it was more crowded as compared to PPR Kerinchi Lembah Pantai. Thus, PPR Pantai Ria, which was more crowded with smaller roads and smaller apartment units, exhibited a higher percentage of extremely severe states of depression, anxiety and stress.

Table 3: Density per acre estimation of the residential area

\begin{tabular}{lrcrrr}
\hline Location & Acreage & $\begin{array}{c}\text { Number of } \\
\text { units }\end{array}$ & $\begin{array}{c}\text { Density } \\
\text { person/acre }\end{array}$ & $\begin{array}{c}\text { Size of apartment } \\
\text { unit }\end{array}$ \\
\hline $\begin{array}{l}\text { PPR Kerinchi } \\
\text { Lembah Pantai }\end{array}$ & 11.12 & 1896 & 853 & $800 \mathrm{sqf}$ \\
\hline PPR Pantai Ria & 9.41 & 1264 & 672 & $750 \mathrm{sqf}$ \\
\hline
\end{tabular}

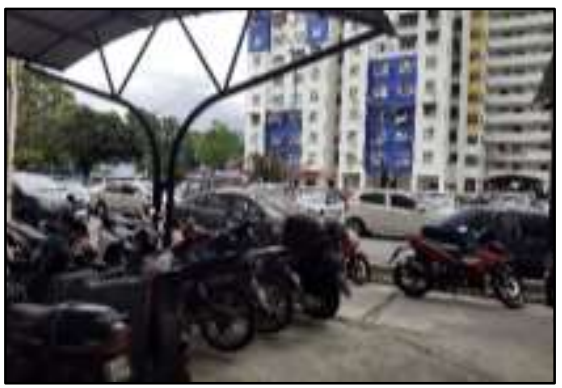

Photo 1: Crowded parking spaces at PPR Pantai Ria

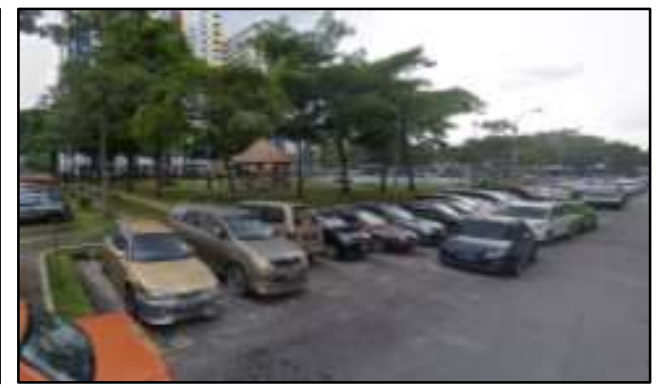

Photo 2: Less crowded parking spaces with green spaces at PPR Kerinchi Lembah Pantai 


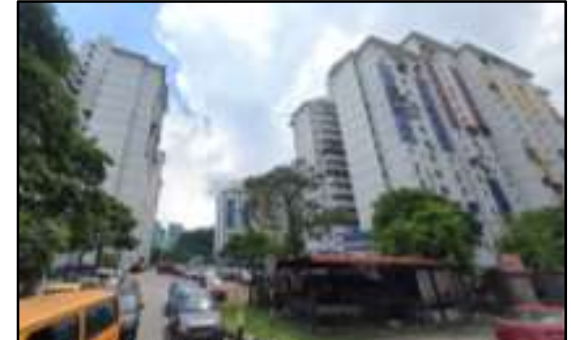

Photo 3: PPR Kerinchi Lembah Pantai residential building

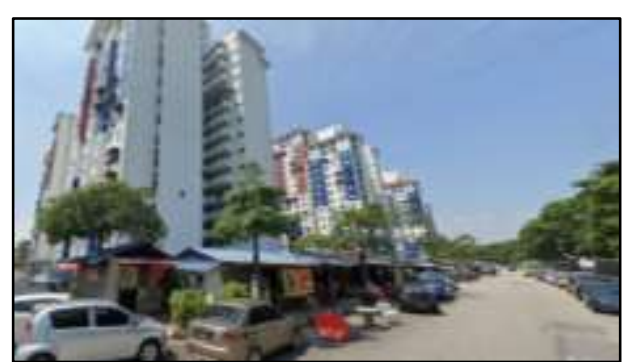

Photo 4: PPR Pantai Ria residential building

Based on the results shown in Table 4, the number of respondents feeling anxious in crowded spaces was similar for both PPR Pantai Ria and PPR Kerinchi Lembah Pantai. There were 31 respondents $(60.8 \%)$ who did not have an anxiety feeling at crowded spaces, while 3 respondents $(5.9 \%)$ had a feeling of anxiety at a good part of the time. For the "experience trembling when they are in crowded spaces" and "stress feeling in crowded spaces", there was a slightly higher percentage of respondents at PPR Pantai Ria who experienced trembling and stress feeling in crowded spaces during "a good part of the time" or "most of the time" (see Table 4). The data showed a higher mental health problem in more crowded area, for example, PPR Pantai Ria with smaller size of apartment units and smaller roads.

The density for both PPR areas exceeded the proper amount of 400 people per acre as provided in the Kuala Lumpur City Plan guidelines for density. Overcrowding would cause an insufficient provision of facilities as the number of users exceeded the provision. When the density for person per acre exceeded the limit provided by the authority, it could cause several problems, such as inadequate car park, as well as inadequate green spaces and service. This implied that the crowded environment had affected the state of mental health of the residents.

Table 4: The respondents' opinions about their feeling when they are at home

\begin{tabular}{|c|c|c|c|c|c|c|c|}
\hline Justification & Area & & 1 & 2 & 3 & 4 & Total \\
\hline \multirow{6}{*}{$\begin{array}{l}\text { Anxiety feeling } \\
\text { in crowded } \\
\text { spaces }\end{array}$} & \multirow{3}{*}{ Pantai } & Nos. & 31 & 17 & 3 & 0 & 51 \\
\hline & & $\%$ & 60.8 & 33.3 & 5.9 & 0 & 100 \\
\hline & & Mean & & & & & 1.45 \\
\hline & \multirow{3}{*}{$\begin{array}{l}\text { PPR Kerinchi } \\
\text { Lembah } \\
\text { Pantai }\end{array}$} & Nos. & 31 & 17 & 3 & 0 & 51 \\
\hline & & $\%$ & 60.8 & 33.3 & 5.9 & 0 & 100 \\
\hline & & Mean & & & & & 1.45 \\
\hline \multirow{3}{*}{$\begin{array}{l}\text { Experiencing } \\
\text { trembling in } \\
\text { crowded spaces }\end{array}$} & \multirow{3}{*}{$\begin{array}{l}\text { PPR } \\
\text { Ria }\end{array}$} & Nos. & 35 & 13 & 2 & 1 & 51 \\
\hline & & $\%$ & 68.6 & 25.5 & 3.9 & 2.0 & 100. \\
\hline & & Mean & & & & & 1.39 \\
\hline
\end{tabular}


Marzukhi, M.A., Ghazali, M.A., Oliver Ling Hoon Leh, Khalid, N.S., Kamaruddin, S.M., Azizul, M.F.

The Influence of Urban Planning on Mental Health. Case Study: Federal Territory of Kuala Lumpur

\begin{tabular}{|c|c|c|c|c|c|c|c|}
\hline \multirow{3}{*}{$\begin{array}{l}\text { (e.g. hands, } \\
\text { body) }\end{array}$} & \multirow{3}{*}{$\begin{array}{l}\text { PPR Kerinchi } \\
\text { Lembah } \\
\text { Pantai }\end{array}$} & Nos. & 36 & 13 & 1 & 1 & 51 \\
\hline & & $\%$ & 70.6 & 25.5 & 2.0 & 2.0 & 100 \\
\hline & & Mean & & & & & 1.35 \\
\hline \multirow{6}{*}{$\begin{array}{l}\text { Stress feeling in } \\
\text { crowded spaces }\end{array}$} & \multirow{3}{*}{$\begin{array}{l}\text { PPR } \\
\text { Ria }\end{array}$} & Nos. & 11 & 23 & 9 & 8 & 51 \\
\hline & & $\%$ & 21.6 & 45.1 & 17.6 & 15.7 & 100 \\
\hline & & Mean & & & & & 2.27 \\
\hline & \multirow{3}{*}{$\begin{array}{l}\text { PPR Kerinchi } \\
\text { Lembah } \\
\text { Pantai }\end{array}$} & Nos. & 11 & 23 & 10 & 7 & 51 \\
\hline & & $\%$ & 21.6 & 45.1 & 19.6 & 13.7 & 100 \\
\hline & & Mean & & & & & 2.25 \\
\hline
\end{tabular}

Note: $1=$ Did not apply to me at all, $2=$ Applied to me some of the time, $3=$ Applied to me a good part of the time, $4=$ Applied to me most of the time

\section{Mental Health and Land Use}

Land use analysis based on Maslow's Hierarchy of Needs (Maslow, 1943; Ryan et al., 2020), which involved five stages. Maslow's theory was a list of human needs that led to a positive mental health. The foundation of Maslow's theory was on physiological needs which were the basic needs for an individual to live. For this study, the first stage of the theory was focused on the residential units or housing as a place to sleep, a food storage and a shelter that had the utility source.

In the second stage, which was about safety and security, it involved the location of the residents to the provision of security facilities, as well as health, such as police station, fire station, clinics, hospitals, and neighbourhood security. If one had fulfilled these two basic needs, their psychological needs were required to be fulfilled. When all the stages were fulfilled, then the final stage which was self-actualisation would be achieved. 
PLANNING MALAYSIA

Journal of the Malaysia Institute of Planners (2020)

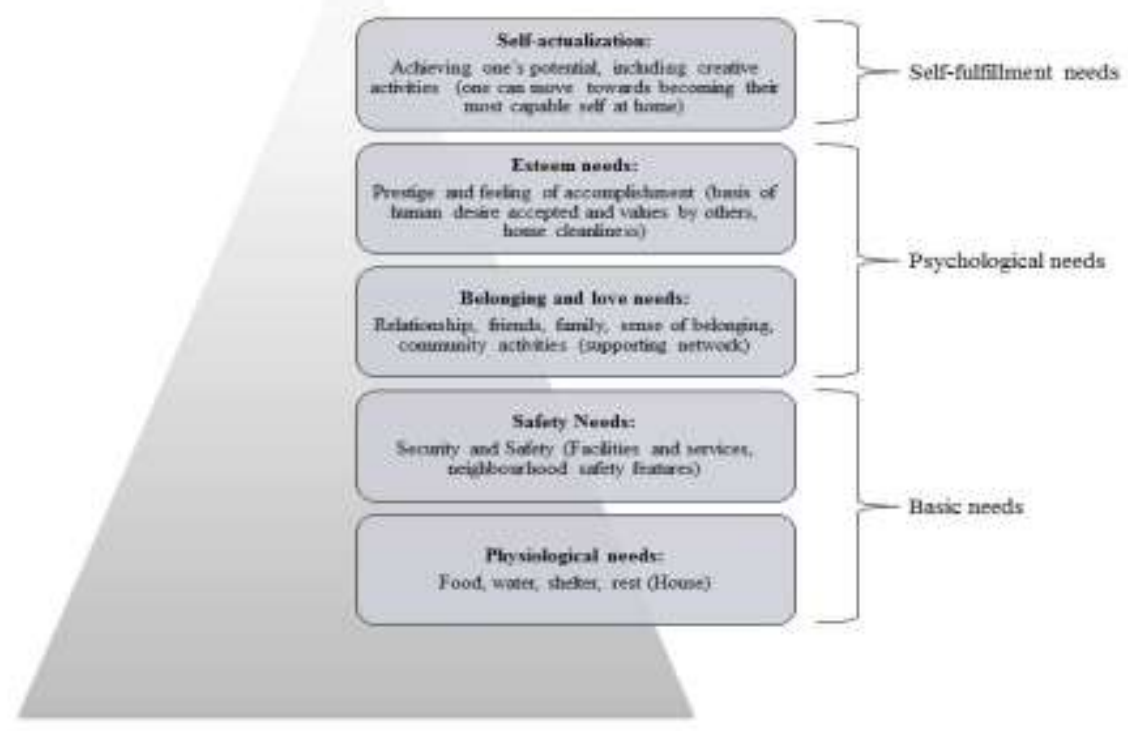

Figure 2: Maslow's Hierarchy of Needs Source: Maslow (1943); Ryan et al. (2020)

Based on the study conducted, in the study area, each unit was provided with three bedrooms with an area of 750 and 800 square feet. Various types of land use surrounded the area of the residential. The important land use types related to Maslow's theories were about safety and security which made residents feeling safe and knowing they would be taken care with various facilities provided, such as police station, fire station and clinics as mentioned in Table 5. The location and distance to these facilities were important as these showed the access level to each facility. All the facilities were within three kilometres from the study area, which was mostly accessible with private transportations.

Based on the land use study, the location of PPR Kerinchi Lembah Pantai had a high accessibility to the facilities and service provided. PPR Kerinchi Lembah Pantai was also surrounded by various types of land use, such as commercials and facilities, including hospital. Its housing was also near to New Pantai Expressway (NPE) and Federal Highway exits as compared to PPR Pantai Ria. PPR Pantai Ria had a high access to Pantai Dalam commuter station. However, the surrounding land use was not supportive as the surrounding land use at PPR Kerinchi Lembah Pantai. The location of PPR Pantai Ria was like an island, in which it was located at the centre of an unplanned residential area, Klang River, New Pantai Expressway, and a sewerage treatment plant. The residents at PPR Pantai Ria would need to travel to commercial centres and 
Marzukhi, M.A., Ghazali, M.A., Oliver Ling Hoon Leh, Khalid, N.S., Kamaruddin, S.M., Azizul, M.F.

The Influence of Urban Planning on Mental Health. Case Study: Federal Territory of Kuala Lumpur

facilities located near to PPR Kerinchi Lembah Pantai or Jalan Klang Lama for any required service. Conversely, both PPR Pantai Ria and PPR Kerinchi Lembah Pantai had community clinics that provided basic health service within their residential areas.

From this analysis, it was noted that PPR Kerinchi Lembah Pantai had a higher accessibility to facilities and service. PPR Kerinchi Lembah Pantai was surrounded by various types of land use as compared to PPR Pantai Ria. Hence, this might have also contributed to the results shown in Table 2, which demonstrated that PPR Pantai Ria had more extremely severe mental health problems as compared to PPR Kerinchi Lembah Pantai. In other words, PPR Pantai Ria with a more crowded environment and a less accessibility to the facilities and surrounding land use displayed a less healthy lifestyle (mentally, as measured by the respondents' opinions and feelings when they are at home, as well as their severity states of depression, anxiety and stress as shown in Tables 2 and 4$)$.

Table 5: Time for Travel Distance to facilities provided

\begin{tabular}{|c|c|c|c|c|}
\hline \multirow[t]{2}{*}{ Location } & \multirow{2}{*}{$\begin{array}{l}\text { Types of } \\
\text { Facilities }\end{array}$} & \multicolumn{3}{|c|}{ Travel Distance (minute) } \\
\hline & & $\begin{array}{l}\text { Private } \\
\text { Transport }\end{array}$ & $\begin{array}{l}\text { Public } \\
\text { Transport }\end{array}$ & Walking \\
\hline $\begin{array}{l}\text { PPR Kerinchi } \\
\text { Lembah Pantai }\end{array}$ & \multirow{2}{*}{$\begin{array}{l}\text { Police } \\
\text { Station }\end{array}$} & 5 & 36 & 26 \\
\hline PPR Pantai Ria & & 6 & 25 & 26 \\
\hline $\begin{array}{l}\text { PPR Kerinchi } \\
\text { Lembah Pantai }\end{array}$ & \multirow[t]{2}{*}{ Fire Station } & 4 & 25 & 28 \\
\hline PPR Pantai Ria & & 5 & 41 & - \\
\hline $\begin{array}{l}\text { PPR Kerinchi } \\
\text { Lembah Pantai }\end{array}$ & \multirow{2}{*}{$\begin{array}{l}\text { Community } \\
\text { Clinic }\end{array}$} & \multicolumn{3}{|c|}{ Within residential area } \\
\hline PPR Pantai Ria & & \multicolumn{3}{|c|}{ Within residential area } \\
\hline $\begin{array}{l}\text { PPR Kerinchi } \\
\text { Lembah Pantai }\end{array}$ & \multirow[t]{2}{*}{ Hospital } & 8 & - & - \\
\hline PPR Pantai Ria & & 9 & 34 & - \\
\hline
\end{tabular}

Pertaining to "comfortability when at home" (see Table 6), it was difficult to say if land use was the underlying factor for this aspect of mental health as a result of inconsistencies with the studies in the previous section. The findings about the respondents' comfortability when they were at home in Table 6 implied that the results were located at the fourth and fifth levels in Maslow's theory of psychological needs. Based on the results presented, more than 50 per cent of respondents had "difficulty to relax at home" for both study areas. However, PPR Kerinchi Lembah Pantai had a slightly higher percentage at "most of their time". The respondents who displayed "feeling agitated when at home" at "some of the time" were observed to have a slightly higher percentage at PPR 
Kerinchi Lembah Pantai as compared to PPR Pantai Ria. In the previous section, it was suggested that PPR Kerinchi Lembah Pantai had better mental health, more facilities and service, as well as land use types surrounded the residential areas as compared to the PPR Pantai Ria. The results did not shed much light on the relation with the surrounding land use and provision of facilities and service.

Table 6: The respondents' comfortability when they are at home

\begin{tabular}{|c|c|c|c|c|c|c|c|}
\hline Justification & Area & & 1 & 2 & 3 & 4 & Total \\
\hline \multirow{6}{*}{$\begin{array}{l}\text { Difficulty to } \\
\text { relax at home }\end{array}$} & \multirow[t]{3}{*}{ PPR Pantai Ria } & Nos. & 21 & 20 & 3 & 7 & 51 \\
\hline & & $\%$ & 41.2 & 39.2 & 5.9 & 13.7 & 100 \\
\hline & & Mean & & & & & 1.92 \\
\hline & \multirow{3}{*}{$\begin{array}{l}\text { PPR Kerinchi } \\
\text { Lembah Pantai }\end{array}$} & Nos. & 21 & 19 & 3 & 8 & 51 \\
\hline & & $\%$ & 41.2 & 37.3 & 5.9 & 15.7 & 100 \\
\hline & & Mean & & & & & 1.96 \\
\hline \multirow{6}{*}{$\begin{array}{l}\text { Feeling agitated } \\
\text { when at home }\end{array}$} & \multirow[t]{3}{*}{ PPR Pantai Ria } & Nos. & 38 & 5 & 7 & 1 & 51 \\
\hline & & $\%$ & 74.5 & 9.8 & 13.7 & 2.0 & 100 \\
\hline & & Mean & & & & & 1.43 \\
\hline & \multirow{3}{*}{$\begin{array}{l}\text { PPR Kerinchi } \\
\text { Lembah Pantai }\end{array}$} & Nos. & 37 & 6 & 7 & 1 & 51 \\
\hline & & $\%$ & 72.5 & 11.8 & 13.7 & 2.0 & 100 \\
\hline & & Mean & & & & & 1.45 \\
\hline
\end{tabular}

Note: $1=$ Did not apply to me at all, $2=$ Applied to me some of the time, $3=$ Applied to me a good part of the time, $4=$ Applied to me most of the time

The results in Table 7 represented the top level in Maslow's theory, in which each individual became capable and creative at his or her own space at the self-actualisation stage. Based on the results shown, for the respondents having difficulties in working up the initiatives at home, the percentage was slightly higher at PPR Pantai Ria. This finding may be a direct consequence of depression as it is consistent with the finding in Table 2. On a contrary, the respondents who felt downhearted and blue when they were at home most of their time demonstrated a slightly higher percentage at PPR Kerinchi Lembah Pantai as cmpared to PPR Pantai Ria. This showed that this finding is consistent with the finding at the previous section in Table 6, in which the respondents at PPR Kerinchi Lembah Pantai displayed more percentage of difficulty to relax and feeling agitated when they were at home.

Table 7: The respondents' abilities and feeling when at home

\begin{tabular}{|c|c|c|c|c|c|c|c|c|}
\hline Justification & Area & & & 1 & 2 & 3 & 4 & Total \\
\hline \multirow{5}{*}{$\begin{array}{l}\text { Difficulty to } \\
\text { work up the } \\
\text { initiative } \\
\text { when at home }\end{array}$} & \multirow{3}{*}{$\begin{array}{l}\text { PPR } \\
\text { Ria }\end{array}$} & \multirow[t]{3}{*}{ Pantai } & Nos. & 18 & 16 & 8 & 9 & 51 \\
\hline & & & $\%$ & 35.3 & 31.4 & 15.7 & 17.6 & 100 \\
\hline & & & Mean & & & & & 2.16 \\
\hline & & & Nos. & 18 & 17 & 8 & 8 & 51 \\
\hline & & & $\%$ & 35.3 & 33.3 & 15.7 & 15.7 & 100 \\
\hline
\end{tabular}


Marzukhi, M.A., Ghazali, M.A., Oliver Ling Hoon Leh, Khalid, N.S., Kamaruddin, S.M., Azizul, M.F.

The Influence of Urban Planning on Mental Health. Case Study: Federal Territory of Kuala Lumpur

\begin{tabular}{|c|c|c|c|c|c|c|c|}
\hline & $\begin{array}{l}\text { PPR Kerinchi } \\
\text { Lembah } \\
\text { Pantai }\end{array}$ & Mean & & & & & 2.12 \\
\hline \multirow{6}{*}{$\begin{array}{l}\text { Feeling } \\
\text { downhearted } \\
\text { and blue } \\
\text { when at home }\end{array}$} & \multirow{3}{*}{$\begin{array}{l}\text { PPR Pantai } \\
\text { Ria }\end{array}$} & Nos. & 35 & 6 & 5 & 5 & 51 \\
\hline & & $\%$ & 68.6 & 11.8 & 9.8 & 9.8 & 100 \\
\hline & & Mean & & & & & 1.61 \\
\hline & \multirow{3}{*}{$\begin{array}{l}\text { PPR Kerinchi } \\
\text { Lembah } \\
\text { Pantai }\end{array}$} & Nos. & 35 & 5 & 5 & 6 & 51 \\
\hline & & $\%$ & 68.6 & 9.8 & 9.8 & 11.8 & 100 \\
\hline & & Mean & & & & & 1.65 \\
\hline \multirow{6}{*}{$\begin{array}{l}\text { Unable to } \\
\text { become } \\
\text { enthusiastic } \\
\text { about } \\
\text { anything } \\
\text { when at home }\end{array}$} & \multirow{3}{*}{$\begin{array}{l}\text { PPR } \\
\text { Ria }\end{array}$} & Nos. & 22 & 18 & 5 & 6 & 51 \\
\hline & & $\%$ & 43.1 & 35.3 & 9.8 & 11.8 & 100 \\
\hline & & Mean & & & & & 1.90 \\
\hline & \multirow{3}{*}{$\begin{array}{l}\text { PPR Kerinchi } \\
\text { Lembah } \\
\text { Pantai }\end{array}$} & Nos. & 22 & 18 & 5 & 6 & 51 \\
\hline & & $\%$ & 43.1 & 35.3 & 9.8 & 11.8 & 100 \\
\hline & & Mean & & & & & 1.90 \\
\hline
\end{tabular}

Note: $1=$ Did not apply to me at all, $2=$ Applied to me some of the time, $3=$ Applied to me a good part of the time, $4=$ Applied to me most of the time

This analysis is related to Maslow's theory. In order to achieve the top of needs in Maslow's theory, one must fulfil each level. The final stage displayed that one was able to become his or her most capable self at home and was able to be creative in his or her own spaces. However, based on the analysis done, it was illustrated that the respondents were not comfortable and could not do any initiatives or felt enthusiastic when they were at home. This implied that they did not fulfil the hierarchy of needs in Maslow's theory. Apart from that, the respondents may not meet one of the needs, which caused them not to advance to self-actualisation.

\section{Correlation between respondents' comfortability at home, as well as their abilities and feelings at home}

For relationship analysis, correlation tests had carried out. The tests were conducted to examine the relationship between the respondents' comfortability at home, as well as their abilities and feelings at home (see Table 8). The analyses showed positive and significant correlations between items in Table 6 and Table 7 among respondents.

Table 8: Correlation between comfortability feelings with respondents' abilities at home

\begin{tabular}{clll}
\hline & \multicolumn{3}{c}{ Abilities \& feeling at home } \\
& Difficulty to & Feeling & Unable to \\
& work up the & downhearted & become \\
initiative & and blue & enthusiastic \\
Comfortability & when at & when at & about anything \\
at home & home & home & when at home \\
\hline
\end{tabular}


PLANNING MALAYSIA

Journal of the Malaysia Institute of Planners (2020)

\begin{tabular}{lllll}
\hline \multirow{2}{*}{$\begin{array}{l}\text { Difficulty to relax } \\
\text { at home }\end{array}$} & Coefficient (r) & $.515^{* *}$ & $.467^{* *}$ & $.669^{* *}$ \\
\cline { 2 - 5 } & Significant (p) value & .000 & .000 & .000 \\
\hline $\begin{array}{l}\text { Feeling agitated } \\
\text { when at home }\end{array}$ & Coefficient (r) & $.443^{* *}$ & $.651^{* *}$ & $.477^{* *}$ \\
\cline { 2 - 5 } & Significant (p) value & .000 & .000 & .000 \\
\hline
\end{tabular}

Note: ${ }^{* *}$ significant at 0.01 level

This result (see Table 8 - first row) showed a positive and significant (at 0.01 level) relationship when the respondents had a difficulty feeling to relax at home. This could affect their capabilities and emotions when they were at home. Feeling down-hearted and blue, as well as being unable to become enthusiastic about anything was a symptom of a person having depression. Thus, when a person exhibited a difficult feeling to relax at home, it could lead to depression.

Correlation analysis was also done for the respondents staying at home with an agitated feeling with a difficulty to work up the initiatives, feeling downhearted and blue, as well as being unable to become enthusiastic about anything. The results (see Table 8 - second row) showed a positive and significant relationship (at 0.01 level) that feeling agitated at home may affect the respondents' feeling causing them feeling down-hearted and blue at home, which could lead to depression. This feeling could also cause them to become difficult to work up with initiatives and unable to become enthusiastic about anything when they were at home. Hence, home was supposed to be a place for a person to relax and feel safe from any harm.

\section{SUMMARY AND CONCLUDING REMARKS}

Based on the available data, it was proposed that there was an evidence of high density living with mental disorders by factors of environment overcrowding and in-house crowding. However, land use factors did not clearly show if it was responsible for contributing to mental disorders. There was also no direct evidence which supported the association between land use and mental disorders. On the contrary, there was a significant relationship between the respondents' comfortability feeling when they were at home that could affect their abilities in their own space. Therefore, it is recommended that further work is necessary to find possible associations between land use and mental disorders.

From the results discussed, even though the number of respondents having mental disorder problems was small (see Table 2), it was still important to pay attention to this group of people in order to mitigate the causal or contributing factors. High-density living also affected some people who could not be in crowding spaces and area. This was because they would avoid green spaces, public spaces and socialising that may trigger the mental disorders. It could be explained through Maslow's Hierarchy of Needs theory, in which they did not meet the level as suggested in Maslow's theory pyramid. This caused them not to 
Marzukhi, M.A., Ghazali, M.A., Oliver Ling Hoon Leh, Khalid, N.S., Kamaruddin, S.M., Azizul, M.F.

The Influence of Urban Planning on Mental Health. Case Study: Federal Territory of Kuala Lumpur

meet their self-actualisation. The findings confirmed that individual feelings, comfortability and capabilities in high-density living had an increased risk of mental disorders. As this study employed a cross-sectional design, this design may be useful to study particular aspects of land use associations with mental disorders using longitudinal studies in future studies.

\section{ACKNOWLEDGEMENTS}

The authors would like to express our gratitude to Faculty of Architecture, Planning and Surveying, Universiti Teknologi MARA (UiTM) and Ministry of Higher Education Malaysia through Fundamental Research Grant Scheme (600IRMI/FRGS 5/3 (063/2019)) and (FRGS/1/2018/SSI11/UITM/02/7) for their generous contribution towards this research.

\section{REFERENCES}

Adli, M., Berger, M., Brakemeier, E. L., Engel, L., Fingerhut, J., Gomez-Carrillo, A., Rainer, H., Heinz, A., Mayer, J. H., Mehran, N. Tolaas, S., Walter, H., Weiland, U., \& Stollmann, J. (2017, March). Neurourbanism: Towards New Discipline. Retrieved May 9, 2019, from The Lancet Psychiatry: www.thelancet.com/psychiatry.

BMJ. (2017). Mental illness and injuries: emerging health challenges of urbanisation in South Asia. The BMJ, 357, 1-3.

Byrne, J. (2017). Planners Know Depressingly Little About a City's Impact on Our Mental Health. Retrieved May 5, 2019, from The Conversation: theconversation.com/planners-know-depressingly-little-about-a-citys-impactson-our-mental-health-81098.

Douglas, K. M., Sutton, R. M., \& Cichocka, A. (2017). The psychology of conspiracy theories. Association for Psychological Science 26(6), 538-542.

Evans, G. W. (2003). The built environment and mental health. Journal of Urban Health: Bulletin of the New York Academy of Medicine, 80(4), 536-555.

Fisher, J. E., Andersen, Z. J., Loft, S., \& Pedersen, M. (2017). Opportunities and challenges within urban health and sustainable development. Journal of Current Opinion in Environmental Sustainability, 25, 77-83.

Gruebner, O., Rapp, M. A., Adli, M., Kluge, U., Galea, S., \& Heinz, A. (2017). Cities and Mental Health. Deutsches Ärzteblatt International, 114, 121-127.

Helbich, M. (2018). Toward dynamic urban environmental exposure assessments in mental health research. Environmental Research, 161, 129-135.

Kuala Lumpur Declaration on Cities 2030 (2018). The Ninth Session of the World Urban Forum, Kuala Lumpur. wuf9.org/kualalumpur-declaration/.

Lau, C., Goodloe, J., Eatman-Williams, J., Dudovitz, R., Wentz, S. (2018). Dancetricians: A street dance intervention to improve physical activity self-efficacy and motivation among urban minority school children. Pediatrics, 141(1), 182.

Ling, O. H. L., Siti Nur Afiqah, M. M., Muhammad Solahuddin, H., Marlyana Azyyati, M., Nurul Ashikin, M. (2020). Health and physical activity in urban 
neighburhoods. Case study: Shah Alam city, Selangor, Malaysia. Built Environment Journal, 17(2), 11-20.

Maslow, A. H. (1943). A theory of human motivation. Psychological Review, 50(4), 37096. Retrieved from https://www.simplypsychology.org/maslow.html?fbclid=IwAR2IBI0x9bbVZj YeewIbdunLBbIaENorBjzpaRg-Ycuj0Yewlgrs3BZBcHY.

Miles, R., Coutts, C., \& Mohamadi, A. (2011). Neighborhood Urban Form, Social Environment, and Depression. Journal of Urban Health: Bulletin of the New York Academy of Medicine, 89(1), 1-18.

Nurul Ashikin, M., Ling, O. H. L., Siti Nur Afiqah, M. M., Kadaruddin, A. (2018). Air quality-related human health in an urban region. Case study: State of Selangor, Malaysia. Environment Asia, 11(1), 194-216.

Qiu, Y., Liu, Y., Liu, Y., \& Li, Z. (2019). Exploring the linkage between the neighborhood environment and mental health in Guangzhou, China. International Journal of Environmental Research and Public Health, 16(3206), 1-15.

Rebecchi, A., Buffoli, M., Dettori, M., Appolloni, L., Azara, A., Castiglia, P., D Alessandro, D., \& Capolongo, S. (2019). Walkable Environments and Healthy Urban Moves: Urban Context Features Assessment Framework Experienced in Milan. Sustainability, 11(10), 2778.

Richardson, E.A., Pearce, J., Mitchell, R., \& Kingham, S. (2013). Role of physical activity in the relationship between urban green space and health. Public Health, 127(4), 318-324.

Ryan, B., Coppola, D., Canyon, D., Brickhouse, M., \& Swienton, R. (2020). COVID-19 community stabilization and sustainability framework: An integration of the Maslow hierarchy of needs and social determinants of health. Disaster Medicine and Public Health Preparedness, 1-7. doi:10.1017/dmp.2020.109.

Sarkar, C., \& Webster, C. (2017). Healthy cities of tomorrow: The case for large scale built environment-health studies. Journal of Urban Health, 1-16.

Schema Case Studies (2018). United Nations University: Kuala Lumpur.

The Lancet Psychiatry. (2017). The Lancet. Retrieved May 9, 2019, from www.thelancet.com: https://www.thelancet.com/psychiatry.

The New Urban Agenda. (2017). United Nations: Habitat III Secretariat.

The Star. (2017). Depression: 40\% of Malaysians Will Suffer from Mental Health Issues in Their Lifetime. Retrieved October 30, 2019, from The Star Online: https://www.thestar.com.my/news/nation/2017/04/02/malaysians-will-sufferfrom-mental-health-issues-in-their-lifetime.

Town and Country Planning Act 1976 (Act 172). Law of Malaysia.

United Nations. (2017). New Urban Agenda. Quito, Ecuador: Habitat III Secretariat.

United Nations, Department of Economic and Social Affairs, Population Division. (2016). The world's cities in 2016 - Data booklet. United Nations.

World Health Organization. (2008). Our cities, our health, our future. Kobe City: World Health Organization.

World Health Organization. (2014). Mental Health: A State of Well-being. Retrieved from World Health Organization:

https://www.who.int/features/factfiles/mental_health/en/. 
Marzukhi, M.A., Ghazali, M.A., Oliver Ling Hoon Leh, Khalid, N.S., Kamaruddin, S.M., Azizul, M.F.

The Influence of Urban Planning on Mental Health. Case Study: Federal Territory of Kuala Lumpur

World Health Organization. (2018). Mental Health : Strengthening Our Response. Retrieved April 27, 2019, from World Health Organization: https://www.who.int/en/news-room/fact-sheets/detail/mental-healthstrengthening-our-response.

Received: $15^{\text {th }}$ May 2020. Accepted: $1^{\text {st }}$ Sept 2020 